Milena, J. Tanasijević ${ }^{1}$

Belgrade Metropolitan University, Belgrade, Serbia

Nataša, Z. Janković

University of Belgrade, Teacher Education Faculty, Belgrade, Serbia

\title{
The New Virtual Reality - Teachers' and Students' Perceptions and Experience in English Language Learning and Teaching Online
}

Summary: An invisible, yet cruel virus has made the entire world face a new reality. Regardless of the degree to which online communication had already been used in educational settings before the Covid-19 pandemic, almost no one working in education had a feeling of being ready to work in the new circumstances. The process of migration to emergency remote language teaching and learning was stressful for all stakeholders in education - management, lecturers, students and their parents. Relying on the reflective and descriptive methods, the paper investigates the advantages and disadvantages of digital tools and platforms for remote collaborative learning, primarily ZOOM, Microsoft Teams, Jitsi Meet, and online learning management systems, recognised by the students and teachers within the mandatory and elective General English, ESP and EMI courses at the Teacher Education Faculty, University of Belgrade and Belgrade Metropolitan University. We conducted qualitative research by using structured and unstructured interviews and monitoring students' collaborative work. In the conclusion, the paper emphasises the aspects of educational technologies which have proved to be beneficial for everyone included in the process, without limiting the creativity, development of thinking skills and investigative spirit of students and lecturers while learning and teaching English.

Keywords: teaching English, collaborative learning, online teaching and learning, EMI, educational technology

1 mtanasijevic@hotmail.com 


\section{Introduction}

Living languages seem to have livened up in new spheres of communication. Literary works seem to be leaving traditional hard and paperback covers. Meeting new cultures no longer requires long journeys and packed suitcases. New technologies have arrived. They have the power to connect us easily across the globe and transfer us quickly in time and space. They provide us with completely new forms of materials, tools and accessories. This is the time of change. Whether we want to see it as an advantage of the modern age or as a threat to true life values, or maybe something in between, is a matter of choice, of striking a balance, a matter worth contemplating.

In the world of education, new times also bring new teaching methods and learner expectations. They also require novel pedagogical approaches to learners and to teaching itself. Traditional teacher-oriented practice has long given way to learner-centred teaching methods (Campbell and Kryszewska, 2002; Macaro, 1997; McIntyre et al, 2006; Murdoch and Wilson, 2008; Spratt and Leug, 2000; Yang et al, 2005). The readiness of teachers around the world to abandon the state of rut and embrace new ways of teaching is a different matter altogether (Hooks, 1994 in: Rowan, 2012: 3). Editors Rowan and Bigum (2012) present examples from different schools around the world showing a variety of "understandings of what it means to be a learner, a citizen, a worker in these changed and changing times" (Rowan, 2012: 10) and how new technologies can contribute to such a course of action.

Apart from the qualities of self-reliance and interactivity, modern student-oriented learning also requires an inspiring learning environment, flexibility of the curricula, and acceptance of students' initiative. In the changing times, this means openness to innovative teaching methods, regular adaptations of course contents and the application of new technologies. "The faculty is expected to educate students for life and work in organisations of a knowledge-based society whose core values are the applicability of knowledge, an active attitude towards professional development and permanent education" (Nikolić, 2018: 66). As the author himself quotes (ibid.), "Innovations are a condition for the school not to lag behind the social and technological changes in the reality that is changing intensively every day (Vilotijević, Mandić, 2015: 10)".

We may have thought we had achieved it all. But did we? An invisible, yet cruel virus has made the entire world face a new reality. Regardless of the degree to which online communication had already been used in educational settings before the Covid-19 pandemic, almost no one working in education had a feeling of being ready to work in the new circumstances. This paper presents how the English teachers and students of two academic institutions adjusted while going through changes.

\section{Emergency Remote Teaching and Learning}

Online classrooms have become an inevitable part of our life and our new virtual reality. They are characterised by new forms of teacher-student cooperation. "Transitioning from a traditional faceto-face model of learning to an online format often requires students to accept more responsibility for their learning (Glenn, 2018)", quote Rakich et al. (2020: 226), who emphasise the need for exploring the ways to help both students and instructors "bridge the gap" between traditional and online learning. Since synchronous and asynchronous learning make the essence of online teaching which tends to be student-centred, the utility of digital tools and platforms is of crucial importance. In his reflections on the advantages and disadvantages of both synchronous and asynchronous modes of online education, Beckwith (2020: 48-49) concludes that "it is apparent that some combination of the two that maximizes the advantages and minimizes the disadvantages is the approach that online educators should adapt". 
However, under the given circumstances imposed by the pandemic, not all teachers managed to switch and quickly adjust to the new forms of communication, lesson preparation, content delivery or assessment. For some, it was an opportunity (Janković, Večanski, 2020; Ristić, Vujović, 2020), for others it was a challenge (Casapía, 2020; Đorđić et al., 2021). Recent research conducted at the level of university education in Serbia (Tomović and Aleksić, 2020) shows that most lecturers have divided positions related to the development of certain language skills, assessment and grading while teaching online. What they do agree upon is the preference of the classroom way of teaching. Although they allow for combined classroom and online teaching, online teaching itself is not something they would opt for unless absolutely necessary.

The new forms of work have also initiated the need for a renewed 'pedagogic agility' (Kidd, 2020, acc. to: Kidd and Murray, 2020) and resourcefulness on the part of teachers. Therefore, especially bearing in mind the desirable student-centredness of online teaching, it is important to research the effects of online teaching and assessment as seen by students themselves. Certain informal inquiries and feedback gained from younger generation students indicate that their learning experience in various schools vastly differed and produced dissimilar effects. According to the findings of Đorđić et al. (2021: 101), for instance, there is a statistically significant difference between the answers of elementary school teachers and subject teachers concerning the ease with which their students were able to cope with the set requirements in online classes.

In their review and evaluation of a number of educators' standpoints regarding the benefits and downsides of the use of new technologies in education, Bigum and Kenway (2005) make an effort to balance between the opposing attitudes within this controversial field. While some are in favour of children's independent access to rich sources of information, integrating and applying knowledge in so- phisticated ways, with teachers being only their guides and facilitators, others see the computer revolution as a way to replace education with entertainment, with poor quality information that can easily be accessed and children learning in more and more isolated ways from each other, while advantage is being given to technical competence over the critical elements of educational process (Bigum and Kenway, 2005: 95).

To this we could add that certain advantages of online learning and teaching may even prove to be its disadvantages. For instance, it may be quite relaxing to be casually dressed or enjoy a cup of tea or coffee during the lesson, but the level of relaxation may sometimes exceed the boundaries in terms of student tardiness, alleged presence, cheating in online tests, etc. On the part of the teacher, the question is - does our family life stand in the way of online teaching or is it actually the other way round? Thanks to digital, i.e. mobile, technologies again, many of us have witnessed awkward and funny situations experienced by teachers or learners around the 'online' world. However, we shall focus on their use for proper educational purposes.

Being digital nomads, younger generations naturally expect their teachers to be equally ready to embrace modern technologies. One of the greatest advantages of this sudden shift may be the opportunity to develop critical thinking and self-reflection among both learners and teachers. Additionally, the language culture that we teach them now gets a new dimension - the digital culture of language use, which is an important study topic in its own right (Bjørge, 2007).

While online language teaching and learning has been present in the field of education for decades, it would seem to be a mistake to make it equal to the so-called emergency remote teaching and learning, which was a direct result of the spread of the Covid-19 pandemic. Online language teaching has been researched and developed for a while (Carillo \& Flores, 2020; Ellis et al, 2020; Huang et al, 
2020; Maile et al, 2020; Sepulveda-Escobar \& Morrison, 2020) and the theory behind it has provided a framework for preparing and implementing courses for educators who were working in the field. The abrupt change in the educational settings did not allow for most of the elements of online teaching to take place, which made the entire migration process stressful for each of the stakeholders - management, lecturers, students, and parents.

The traditional process of preparing online courses allows ample time for preparation (Hewett \& Powers, 2007; Bobley \& Best, 2021). This is a crucial stage which, when done properly, allows course developers and lecturers to reflect upon all the choices which need to be made in the process. The reflection process involves students as reflective learners (Bilous et al, 2018: 288) but also teachers analysing the e-learning platforms and digital tools available, evaluating the course material and finding appropriate ways in which it could be used when teaching online, writing and rewriting tasks and explanations and so on. During the preparatory stage, course developers are aware of the expected course outcomes and work around the tools available to them in order to apply them in the online teaching process. The preparatory stage is mostly used for finding the most appropriate answers to questions such as: which teaching methods would work best for the given e-learning platform, which learning strategies could be used, which learning strategies need to be taught given that most students would not have had experience in learning online, how much input should there be, how much scaffolding should there be, is the input comprehensible enough (especially for mixed-level groups), how to motivate students to keep going in order to prevent dropping out, how to take the emotional factors into account (would some students feel awkward when doing a certain task online)? All these questions and dilemmas are resolved in the preparatory stage when teaching online. What happened in the spring of 2020 was everything but that. The emergency of the migration to online teaching did not allow anyone involved in the education process to adjust and to prepare. The result was a feeling of anxiety and stress. Lecturers all around the world needed to adapt to the new reality very fast, while trying to retain their self-confidence and authority.

\section{Educational Technology and Remote Collaborative Learning}

Online education places emphasis on much more flexible approaches to teaching and the use of many more learning resources than traditional education. The effects of teaching do not only depend on the teacher-student interaction. Apart from a necessary increase in the use of flexible delivery methods, what is essential is the quality of studentstudent interaction as well. This particularly refers to university education (Curtis \& Lawson, 2001: 21). According to Dillenbourg and Schneider (1995), in collaborative learning subjects "often share the cognitive burden implied by the task [...] in which two or more subjects build synchronously and interactively a joint solution to some problem", spontaneously distributing the cognitive sub-tasks over individuals. Collaborative learning is one of the crucial forms of student interaction.

Another important aspect of one's cognitive and academic development is experiential learning (Kolb, 1984). However, it is reflecting upon the experience that we truly learn from, according to Dewey: "To reflect is to look back over what has been done so as to extract the net meanings, which are the capital stock for intelligent dealing with further experiences. It is the heart of intellectual organization and of the disciplined mind" (Dewey, 1997: 87). Since many factors impact what happens in the classroom, thus making teaching and learning equally complex, "there is no one correct and universally applicable approach to teaching", says N. Brown ${ }^{2}$, adding that: "Teachers need to constantly adapt and change their

2 https://www.nicole-brown.co.uk/teaching-and-reflectivepractice/ 
activities and plans accordingly. And in order to do just that in an efficient and effective way, teachers must be reflective." Such practice, as this study will show, is beneficial for both students and teachers.

Educational technology enriches and facilitates an array of life processes, and improves the training of future professionals. This is of particular importance in teacher education, as "technology can make good teaching even better, while it cannot fundamentally improve poor teaching" (Janković and Ristić, 2018: 39). In the education of foreign language (FL) teachers, educational technology is a supplement which gives both language learning and teaching a new dimension. Although it is primarily based on the application of digital technologies, these are just one in a range of factors that contribute to the fulfilment of the teaching goals. Therefore, according to the same authors, it is necessary to create educational situations that will contribute to students' academic achievement, cognitive development, and the development of other value-related aspects of personality (ibid.).

Considering the significance of information communication technologies in foreign language teaching, Gojkov-Rajić and Šafranj (2018) say that the new age also imposes new trends in learning Languages for Specific Purposes (LSP), such as lifelong learning, where active individuals need to deal with gathered information. Therefore, as the authors say, students should be taught to independently find new information, manage it, analyse it and turn it into useful knowledge (Gojkov-Rajić, Šafranj, 2018: 24).

Comparing the aspects of asynchronous and synchronous discussions in computer-mediated communication (CMC) among learners of English as a second language, Sotillo (2000) concludes that synchronous discussions resemble interactional modifications found in face-to-face conversations which are deemed necessary for second language acquisition, while asynchronous discussions result in more constrained discourse functions (rather resembling the traditional question-response se- quences), though they provide learners with more opportunities to produce syntactically complex language. Therefore, Sotillo believes that: "In the hands of experienced teachers, both modes of CMC can be used as novel tools to enhance the language acquisition process by encouraging interaction among participants, collaborative text construction, and the formation of electronic communities of learners" (Sotillo, 2000: 82). The following chapters will show how it was achieved in the two institutions included in the study.

\section{Research Methodology}

The aim of this paper is to investigate the experience of teaching and learning English online at the onset of and during the Covid-19 pandemic for both lecturers and students. In order to achieve the research aim, the authors conducted a qualitative study: a) by conducting a structured interview with a focus group of 10 selected students at Belgrade Metropolitan University (BMU), and b) by monitoring a focus group of 7 selected students engaged in a collaborative project-based task at the Teacher Education Faculty, University of Belgrade (TEF). Relying on the descriptive and reflective methods, the paper first presents the context in which English language lecturers of the two university institutions sought the best path forward in terms of using digital tools and platforms for remote individual and collaborative learning, primarily ZOOM, Microsoft Teams, Jitsi Meet, and online learning management systems. The paper investigates their advantages and disadvantages recognised within the mandatory and elective General English, ESP and EMI-based courses taught at both institutions and the effects of their application.

\section{Data collection and research instruments}

a) In order to investigate the learning experience of students at BMU, we conducted a structured interview with a focus group of students. 
The focus group consisted of ten students who were studying the same general English course - English 2, during the spring semester in 2020. The students were randomly selected from the entire population. The interview was conducted over Zoom and the students were asked to assess if it was more difficult to learn English once they had to swiftly accommodate to studying online. There were six broad questions, divided into sub-sections, as well as a comment section (Appendix 1). The questions were organised in the following main fields:

1. Perceptions regarding learning online (How they found learning English online - more or less difficult than learning in the classroom, if they could describe the main differences, if they could describe the user experience of the e-learning platform LAMS);

2. Approaches to online language learning (if it is easier or more difficult to practise all the language skills online; how different it is to learn grammar and vocabulary online);

3. Motivation (if it is easier or more difficult to keep the motivation level high when learning online);

4. Course evaluation (how they would evaluate the entire course once it was moved online);

5. Perceptions about the challenges when learning a foreign language online;

6. Perceptions about the perspectives when learning a foreign language online.

b) In order to investigate the collaborative learning experience of students at TEF, we systematically monitored a focus group of students and analysed their progress through ongoing unstructured interviews while they were preparing a presentation and a workshop to deliver at a professional language teachers' conference. The focus group consisted of seven students who were studying the same elective
EMI-based courses in the third and fourth year of studies during the spring semester of 2021. The interviews were conducted within a five-month period over Microsoft Teams.

Being non-directive by their nature, such interviews do not require any set of predetermined questions, but allow the interviewer to initiate communicative exchanges by asking open-ended questions on the research topic and letting the interview "go with the flow", like a natural conversation (Patton, 2002; McLeod, 2014). Therefore, during each of the six interview sessions, the students were asked to reflect on their progress, with the lecturer providing feedback and giving further guidance.

The initial interview session was conducted at the beginning of December 2020 in order to form the two teams - one for the conference presentation and one for the workshop.

The other five interview sessions were conducted once a month from December 2020 to April 2021, each following a step in the process of preparing the presentation and the workshop.

\section{The context of the study}

The participants in the study were selected from the overall population of attendees studying three general English (GE) language courses, six ESP courses and twelve elective EMI-based courses at BMU and TEF. The total number of students included in the online courses was:

- second semester of 2019/20 - approximately 390 in GE courses and 44 attending four EMI-based elective courses; ESP courses at both institutions had already been completed at the moment of transfer to online teaching in March 2020;

- first semester of 2020/21 - approximately 390 in GE courses, 445 in ESP courses and two groups with a total of 23 students attending five different EMI-based elective courses; 
- second semester of 2020/21 - approximately 390 students in GE courses and 55 students attending five different EMIbased elective courses.

The compulsory General English courses are conducted at B1-B2 CEFR levels, the compulsory ESP courses at B2 level, and the elective EMI-based courses at B2-C1 levels. The total number of English language teachers included in online teaching in these two academic institutions is seven. In the text below, we will present the courses more closely.

\section{English Language Courses at}

\section{Belgrade Metropolitan University}

At Belgrade Metropolitan University, the following courses were taught online in the mentioned period of academic years 2019/20 and 2020/21:

Students at Belgrade Metropolitan University are enrolled at three faculties - Faculty of Information Technologies, Faculty of Digital Arts and Faculty of Management. There are three compulsory English courses at bachelor studies, lasting one semester each: two General English courses at B1 and B2 levels and four different ESP courses at the B2 level - English for IT, English for Management, English for Design and English for Fashion Design. Students are expected to attend lectures and to participate in class discussions. The assessment process is both formative and summative. Students' work is evaluated through homework tasks (extended essays), home reading assignments, projects, presentations, progress tests, as well as a formal exam test.

BMU uses a learning management system developed by the university itself called LAMS ("Learning Activity Management System"), which allows lecturers to prepare the entire course material in advance. The course material is regularly uploaded to the LAMS platform prior to the course beginning since BMU has had a cohort of students studying online since 2005. Students who have enrolled to study online have not been included in this research.
The rapid spread of Covid-19 led to the entire teaching process being held online in March 2020. All the classes were held live online via Zoom according to the timetable set and the final exams were held on the University premises. The change was sudden and practically overnight. Although the faculty and the students were familiar with the elearning platform and the tools it provides, this rapid shift led to a lot of stress and anxiety. The faculty was rehearsing and analysing Zoom, with assistance from peers, colleagues and students themselves.

\section{Digital Technologies Used at BMU}

\section{LAMS}

The e-learning platform used by BMU is a project developed by IT experts working at the University. Software development is an on-going process which leads to constant improvement and additional options added to it (Trajanović, Domazet, Mišić Ilić, 2007; Trajanović, Mišić, 2010; Vukotić, Tanasijević, 2012; Tanasijević, Vukotić, 2014). The current state of the e-learning platform allows lecturers and students to upload content to it. The software used for the preparation of lectures is called 'mdita' and it allows lecturers to structure lessons the way they are to be conducted in the traditional classroom. The file packages are prepared as a kind of presentation with additional tools allowing for $\mathrm{Q}$ \& A sessions, quick assessments (multiple choice exercises, true-false activities, open-ended questions), forum discussions, upload of video and audio content, as well as images, graphs, charts and tables. Students prepare their homework tasks and project assignments and submit them to their lecturer by email.

The platform itself has been improved to a large degree. Although it has not been developed for language teaching and learning primarily, it does cater for many pedagogical needs of language learners. The lectures are available to students at any time during the day. They can read and do the tasks at their own pace and at times most convenient to 
them. The lecture material can be revisited as many times as needed. The affective factors which contribute to successful language learning can be easily met - students do not need to feel overcome or intimidated when doing tasks, they can use other digital resources to help them in the process, they do not feel pressured to respond immediately and they can fine-tune their replies.

In terms of language learning and teaching pedagogy, the platform does not offer possibilities for introducing gap-fill type of activities, or matching exercises.

\section{ZOOM}

Upon migration of the courses to the online environment, BMU opted for Zoom for conducting live lessons. It took a while for all the lecturers to become familiar with it. There was not sufficient time for research and practice, which led to us learning how it works by doing. However, there was an aura of enthusiasm and curiosity by all of us, both lecturers and students. Students were at times instrumental in helping and guiding us during the process. Once we all became familiar with the options Zoom offers, it became a little easier. The natural feeling of self-confidence and ease which a lecturer brings to the classroom, which mostly stems from being thoroughly prepared for the lesson, was gradually being built. Students participated in classes to a large degree. Zoom provides the possibility of sharing files and audio content, as well as participation through chat or by speaking. However, there were problems with slow or no internet connections and no use of camera on the part of students. We believe that there should be caution exercised when insisting on turning on cameras, since some students might face slower internet speed due to it and some students might not be willing to share their immediate surroundings with a wider group of people. The Covid-19 pandemic made us work on Zoom for far longer than initially expected. With time, the level of enthusiasm had dropped and it became more and more difficult to keep the students motivated to attend and participate in classes.

\section{English Language Courses at the Teacher Education Faculty}

At the Teacher Education Faculty of the University of Belgrade, students are enrolled in one of two study programmes - for primary school teachers or for preschool teachers, who will be working with young and very young learners. Foreign language is a compulsory course at TEF, though elective in terms of the choice of the language: English, German, Russian or French. An additional integral part of the undergraduate and master studies also prepares a small group of gifted students in each generation, enrolled with a minimum of $\mathrm{B} 1+$ level, for teaching English to young and very young learners within the English Language Module (ELM). The Teacher Education Faculty offers to its students one GE course at the B1+ level, two ESP courses at the B1+ and B2 levels, as well as twelve EMI-based courses at the B2-C1 level. The elective courses addressed in this study are specially designed for the gifted ELM students.

The platform officially used for the purposes of online teaching at TEF is primarily Microsoft Teams. Jitsi Meet was a temporary solution for some of the ELM lessons, before most of the benefits of Microsoft Teams were fully explored and put into use.

Bearing in mind the large groups in most language classes, and following the instructions issued by the authorities, all the above-mentioned courses were fully taught in the online regime from the end of March 2020 till the end of June 2021. The assessment process was both formative and summative. Written exams were held on the faculty premises under restrictive measures, while most of the oral exams were held online, except for those that require practical activities and demonstrations, especially within the ELM courses. 


\section{Digital Technology Used at TEF}

\section{Microsoft Teams}

Microsoft Teams is useful for communication with large groups of participants for non-limited periods of time. Meetings can be scheduled in advance, recorded in the calendar, and started by the users either from within the platform itself or by following the shared link. The platform supports simultaneous work in split groups or breakout rooms, which makes it very convenient for both university classes and professional gatherings. Its additional advantages are the options for sharing materials, their upload, download and editing in either synchronous or asynchronous manner, the Class Notebook for students' notes with a canvas for collaboration, and specially designated space for assignments, grades and reflective insights. Particularly useful for the teacher is the possibility to download lists of participants and thus keep a record of students' attendance, while the learners can vastly benefit from the recordings of lessons that the teachers can make and keep automatically saved in their shared Team folders for later viewing.

The controls for manipulation during communication (use of microphone, camera, chat, screen sharing, hand emoticons and toggle tile view) and refined customisation (name and background settings, security and recording options, inviting and muting participants) are also quite helpful. To prevent incidental distractions, the teacher (or event host) can disable other participants' cameras or microphones, though they do not have the possibility to annul this function, so the students have to do it themselves if they want to be heard or seen. What makes this collaboration platform rather complex for use is its reliance on the Microsoft 365 family of products, which required opening accounts for all of the Faculty's students and teachers and undergoing initial training in order for many to grasp its full potential. This was provided by the Faculty's highly professional IT staff, and after the first uncertain steps, with time, most users gradually learnt how to use MS Teams for their teaching and learning purposes.

\section{Iitsi Meet}

Jitsi Meet is an open source video conferencing solution that does not require having an account. It provides much simpler lesson scheduling and log-in procedures. Meetings can be easily titled and participants invited by sending the link to their e-mail addresses. Due to its ease of use and similarities with other broadly applied computer software programmes, like Skype, its advantages are: unlimited access for up to 100 participants, unrestricted session length, the possibility of sharing the screen to present textual, audio or video contents, creating polls and using the chat option. Its controls for communication and customisation are mainly the same and as useful as those of the MS Teams.

However, Jitsi Meet does not enable the download of the list of attendees, but only seeing (and taking screenshots of) the Speaker Stats during the meeting, which makes the teacher's job of record keeping much more complicated. Its other major limitation is no option for material upload and download. Therefore, to "build synchronously and interactively a joint solution to some problem" in a collaborative learning task (Dillenbourg and Schneider, 1995), these subjects and their teachers must rely on other solutions besides live video-conferencing, such as: Google Drive uploads, WeTransfer exchanges, sharing textual materials and images via e-mail, "distributing the cognitive sub-tasks" (ibid.) while preparing Power Point presentations and mutually communicating through their Facebook, Viber, WhatsApp or other chat groups, etc. These forms of asynchronous communication have generally proved to be useful in many teaching contexts since the time of the pandemic breakout. 


\section{Research results}

\section{BMU Students' Perceptions and Reflections on English Language Learning Online}

The results of the structured interview with the focus group of ten students revealed that the students agreed to a large extent within each of the following six groups of questions (Appendix 1):

1 Perceptions and overall impressions regarding the differences between learning online and traditional learning in the classroom - seven students did not find any significant difference between online and traditional language learning, two students stated it was unusual in the beginning, while one student answered that studying online was much more convenient.

2 Perceptions about the level of difficulty of online language learning - there were six sub-questions asking the students to state whether learning online was more difficult than traditional learning when building the four language skills: reading, listening, writing and speaking, as well as learning grammar and vocabulary. All the students felt the same about the difficulty of practising the four language skills online (including preparing and delivering presentations) as they did in the traditional context, except for one student, who found it easier to focus on the listening tasks online, and another student, who thought that practising speaking was easier online as she had more time to prepare her answers.

3 Motivation - the question on motivation yielded interesting results, as four students answered they needed time to adjust to the new learning circumstances; one student found it less motivating because he was "studying from home". The remaining five students felt no change in the level of motivation.

4 Course evaluation - the course delivery was highly evaluated by everyone.
5 Perceptions about the challenges when learning a foreign language online - nine students could not state any particular challenges when learning English online. One student found it unusual to be active when working online at the beginning of the online course because "it felt unnatural".

6 Perceptions about the perspectives when learning a foreign language online - nine students could not see any particular perspectives related to online language learning. One student observed that it was and could be beneficial for students to be able to study physically separated from others because it was "good for concentration, unlike the classroom, where there are frequent disruptions".

None of the ten students had any additional comments.

\section{Remote Collaborative Work at TEF}

The unstructured interviews with the TEF students led to collaborative work which resulted in a successfully delivered presentation and workshop at the LSP conference organised by the Foreign Language and Literature Association of Serbia and hosted online over MS Teams by the Teacher Education Faculty in April 2021.

The first interview session in December 2020 was conducted with two separate focus groups of students, in order to hear their own reflections on their L2 development within the English Language Module, with the aim of forming two collaborative teams. Based on their feeling of self-confidence in L2 and a high level of motivation, seven students volunteered to be conference presenters. The first interview session resulted in forming a group of three speakers (out of 11 interviewed) for the PowerPoint presentation and another group of four speakers (out of 12 interviewed) for the workshop.

During the second interview session, the students were asked to reflect on their knowledge of ESP and experience of using digital and language skills acquired within the elective EMI-based courses attended until then. Based on these reflections, 
the meeting resulted in students distributing the sub-tasks among themselves, with each of them presenting a brief plan of the contents they would include in their own parts of the presentation or workshop.

The third session of interviews was conducted separately with the Presentation Team and the Workshop Team in order to focus on specific details they planned to present based on the variety of integrated contents and skills acquired through the ELM. Additionally, each student within their respective group reported on the planned layout of the PowerPoint presentation. They were given guidance related to the further steps to be taken, especially with reference to conducting an online survey planned by one of the senior generation students.

The fourth session was arranged after the student survey had been conducted online and both teams given time to compose their abstract proposals as conference applicants. With the teacher's feedback and guidance, the final versions of the abstracts were composed and ready to be submitted to the LSP event's organising committee.
The fifth session was planned for presenting the results of collaboratively and individually prepared contents, slides and activities within each group and as an opportunity for the two teams to give each other peer feedback, exchange opinions and reflect on the opposite group's work. This form of online cooperation helped the students finalise their work.

The sixth and final session was devoted to practising the delivery of the contents. Both teams rehearsed presenting their completed tasks. Attention was especially paid to proper language use, pronunciation, screen sharing and timing in order for the students to alleviate anxiety which was growing as the date of the conference was approaching.

As a result, the academic paper presentation "Ready, Steady, Know!" and the workshop "ESP in Motion" were delivered via MS Teams during the online professional LSP conference on $25^{\text {th }}$ April by collaborative Team 1 (Staletović, Kosić and Lazarević - Picture 1) and collaborative Team 2 (Stanić, Heinrih, Pankalujić and Martinović - Picture 2) respectively.

Picture 1. Results of remote collaborative learning by doing of TEF's fourth-year ELM students

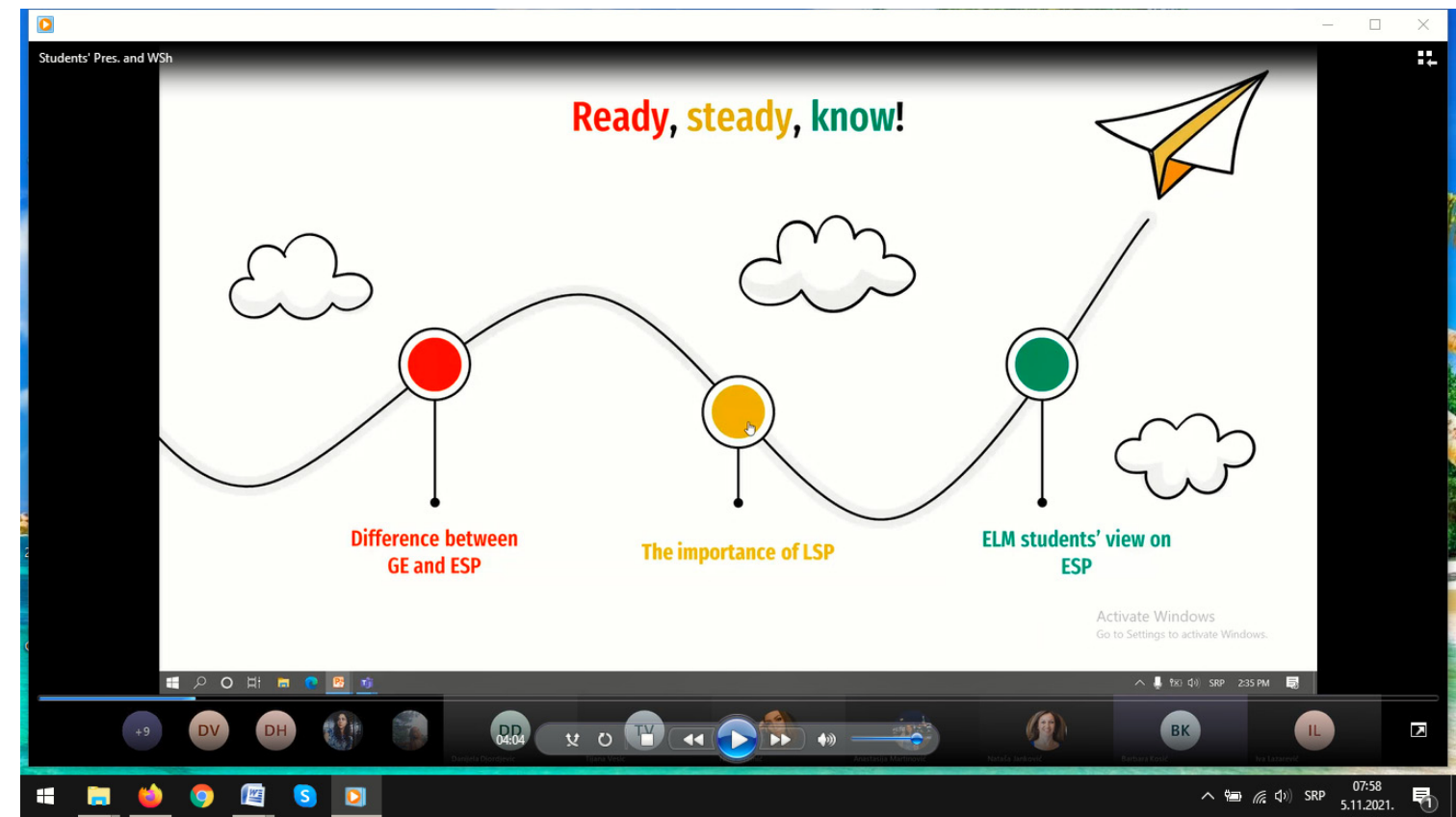


Picture 2. Results of remote collaborative learning by doing of TEF's third-year ELM students

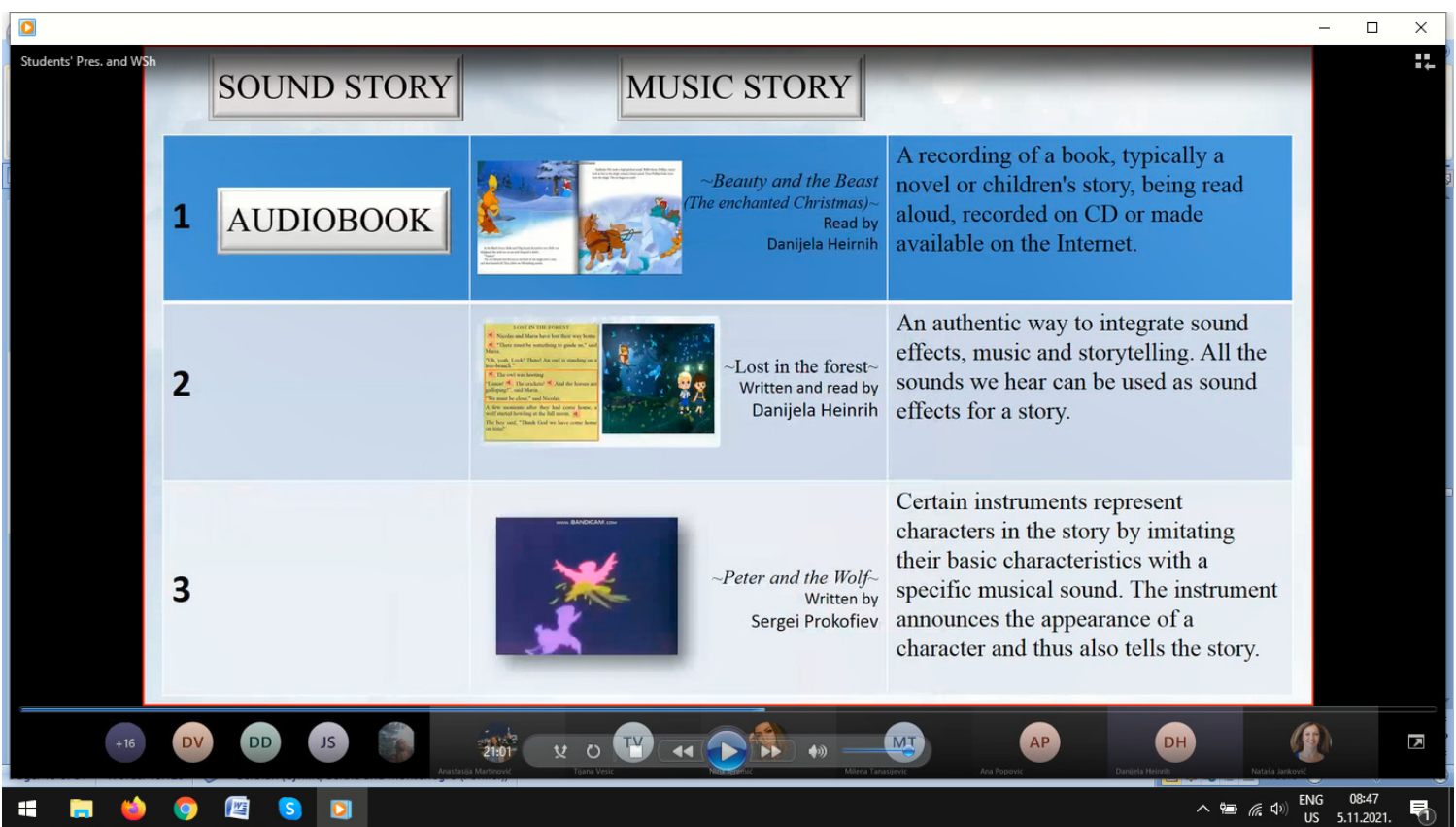

Having delivered their presentations entirely in English, the undergraduates received compliments from experienced in-service EL teachers, who addressed the participants in speech:

"I also wanted to say how much I enjoyed the presentation. It was excellently delivered and very interesting, and I would never have been able to tell that it's your students' first presentation. So, bravo to Iva, Barbara and Marija! You did a great job. [...] And it was especially gratifying to hear that you are not just passive participants, but you're also the cocreators of the modules. So, that's, I think, a very important thing." (A. Popović)

Inviting the workshop attendees to write their feedback in the chatbox, the younger team also received multiple compliments, e.g.: "This workshop was amazing. Excellent! We are so proud of you." (M. Cvetković). "Very interesting and useful game activity" (I. Turubarova). "It was a lot of fun and very useful, too" (V. Ivanova).
The conference paper and presentation "Ready, Steady, Know!" included an important aspect of scientific research, i.e. a questionnaire distributed online by one of the student-presenters (M. Staletović) among all the English Language Module students in the four generations, receiving 53 responses, a segment of which is presented in Picture 3.

As shown above, based on the threeand four-year study within the ELM, as well as reflective and collaborative learning by doing, the students' work resulted in serious scientific research and conference presentations. What these future preschool and primary school teachers managed to show in the online event attended by LSP professionals from 20 countries was an excellent approach to the use of digital technology for teaching purposes presented in high-quality English. 
Picture 3. A result of students' scientific research conducted and presented online

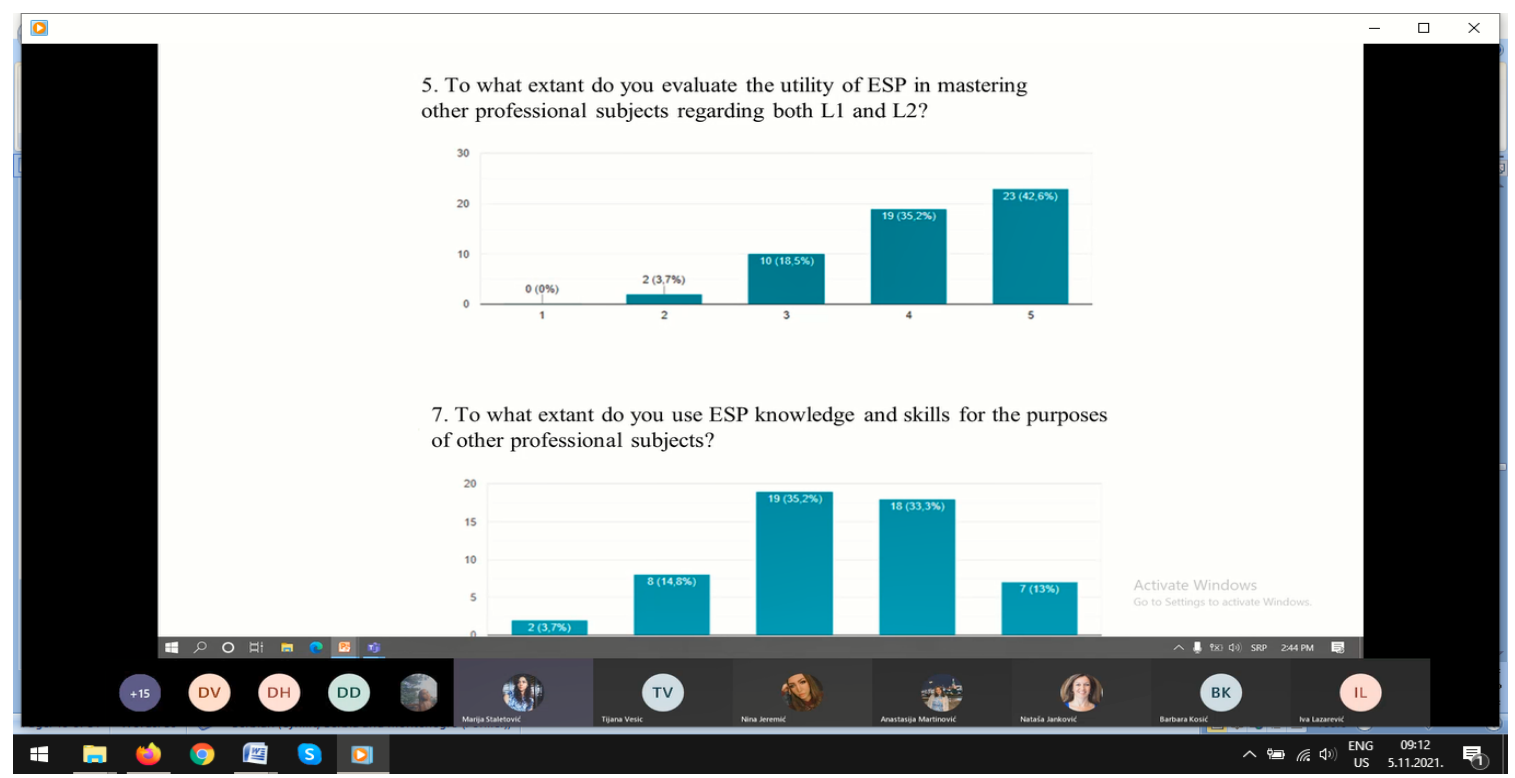

\section{Conclusion}

This is the time of change. Whether we see it as an advantage, an obstacle, or something in between, it certainly requires a shift from traditional to more modern approaches to learning and teaching. The outbreak of Covid-19 also brought with itself new forms of reflective thinking and remote collaborative learing. In a situation when we are experiencing a tremendous leap into virtual reality, "the integration of all teachers' and learners' knowledge and skills, the use of various modern means that we have at our disposal and an orientation to globally acceptable systems of education are bound to provide a meaningful educational context in the era of globalization" (Janković, 2007: 148).

The aim of this qualitative research was to investigate the experience of teaching and learning English online. Relying on the descriptive and reflective methods and focus group interviews, the paper presents the students' and teachers' experience of using digital tools and platforms for remote col- laborative learning and teaching, such as ZOOM, Microsoft Teams, Jitsi Meet, and online learning management systems, applied at two academic institutions in Belgrade. As shown in the results of the conducted interviews and activities that were the subject of monitoring, students' perceptions and reflections on the learning experience under the new circumstances were positive, and even resulted in presentations created and delivered by some of these undergraduates at an international LSP conference.

We believe such findings can be a stimulus to those who feel less motivated to use new digital tools, applications or platforms and rather rely on a restricted choice of synchronous and asynchronous forms of working online. Similar research with larger populations of university students and teachers could provide additional valuable insights into the subject matter in academic circles. Also, bearing in mind the impressions shared in class discussions by the newly arrived first-year students, it would be very useful to see the results of similar research conducted among high school students and teachers as 
well, especially in terms of productivity and creativity, and to compare their reflections on online learning, teaching and assessment with those of university students and lecturers.

Despite the divided positions of university and other teachers concerning the benefits and downsides of online work compared to regular classroom interaction, and certain motivational obstacles reported by students, these examples show the aspects of educational technologies which have proved to be beneficial for everyone included in the process. Additionally, this was achieved without limiting the creativity, development of thinking skills and investigative spirit of students and lecturers learning and teaching English.

Without educational technology on their side, these generations of students would not have been able to truly develop academically in the times of sudden change. The atmosphere of mutual trust and the shared learning-teaching roles during the months of collaborative online work have vastly contributed to everyone's personal and professional growth. However unfortunate our new virtual reality may be, the life "in the cloud" has obviously had its share in our students' linguistic, cultural and professional development. As for the teachers, they too have undergone a form of digital acculturation.

\section{References:}

- Beckwith, E. G. (2020). The Importance of Synchronous Sessions in Online Asynchronous Classes. In: SistekChandler, C. M. (Ed.). Exploring Online Learning Through Synchronous and Asynchronous Instructional Methods (34-51). Hershey, PA, USA: IGI Global.

- Bigum, C. \& Kenway, J. (2005). New Information Technologies and the Ambiguous Future of Schooling - Some Possible Scenarios. In: Hargreaves, A. (Ed.). Extending Educational Change (95-115). Netherlands: Springer. DOI: 10.1007/1-4020-4453-4_5

- Bilous, R. H., Hammersley, L. \& Lloyd, K. (2018). Reflective practice as a research method for co-creating curriculum with international partner organisations. International Journal of Work-Integrated Learning, 19 (3), 287-296.

- Bjørge, A. K. (2007). Power distance in English lingua franca email communication. Retrieved September 8, 2021 from www: https://doi.org/10.1111/j.1473-4192.2007.00133.x

- Bobley, L. \& Best, R. (2021). Teacher Preparation during COVID-19: A Shift from Face-to- Face to Remote Field Experiences and Student Teaching. In: INTED2021 Proceedings (9810-9816). INTED2021, 15th Annual International Technology, Education and Development Conference, 8-9 March 2021. IATED Academy, Spain.

- Brown, N. (2021). Teaching and reflective practice. Retrieved November 3, 2021 from www: https://www.nicolebrown.co.uk/teaching-and-reflective-practice/

- Campbell, C. \& Kryszewska, H. (2002). Learner-based Teaching. Resource books for teachers. Oxford: Oxford University Press.

- Carrillo, C. \& Assuncao Flores, M. (2020). COVID-19 and teacher education: a literature review of online teaching and learning practices. European Journal of Teacher Education, 43 (4), 466-487.

- Casapía, R. (2020). Resistance to Change, the Challenge for Universities with Online Education. The challenges that COVID-19 has revealed in higher education in Latin America and the Future of Online Education. Retrieved June 18, 2021 from www: https://egade.tec.mx/en/egade-ideas/research/resistance-change-challenge-universitiesonline-education 
- Common European Framework of Reference for Languages: Learning, Teaching, Assessment. (2001). Cambridge: CUP

- Curtis, D. D. \& Lawson, M. J. (2001). Exploring Collaborative Online Learning. Journal of Asynchronous Learning Network, 5 (1). DOI: 10.24059/olj.v5i1.1885

- Dewey, J. (1997). Experience and Education. New York: Touchstone, Simon \& Schuster Inc.

- Dillenbourg, P. \& Schneider, D. (1995). Collaborative Learning and the Internet. Retrieved September 3, 2021 from www: http://tecfasun1.unige.ch/tecfa/tecfa-research/CMC/colla/iccai95 1.html. ICCAI 95

- Đorđić, D, Cvijetić, M. i Damjanović, R. (2021). Iskustva učitelja i nastavnika tokom realizacije nastave na daljinu usled pandemije virusa korona (COVID-19). Inovacije u nastavi, XXXIV (2), 86-103. DOI: 10.5937/ inovacije2102086D.

- Ellis, V., Steadman, S. \& Mao, Q. (2020). 'Come to a screeching halt': Can change in teacher education during the COVID-19 pandemic be seen as innovation? European Journal of Teacher Education, 43 (4), 559-572.

- Gojkov-Rajić, A. \& Šafranj, J. (2018). Information communication technologies for learning languages for specific purposes. In: Zacłona, Z. \& Radovanović, I. (Eds.). Chosen issues of education in the modern era (23-37). Nowy Sacz: State University of Applied Sciences and Belgrade: Teacher Education Faculty.

- Hewett, B. \& Powers, C. E. (2007). Online teaching and learning: Preparation, development, and organizational communication. Technical Communication Quarterly, 16 (1), 1-11.

- Hooks, B. (1994). Teaching to transgress: Education as the practice of freedom. New York: Routledge.

- Huang, R., Tlili, A., Chang, T.-W., Zhang, X., Nacimbeni, F. \& Burgos, D. (2020). Disrupted classes, undisrupted learning during COVID-19 outbreak in China: application of open educational practices and resources. Smart Learning Environments, 19 (7), 1-15.

- Janković, N. (2007). Learner and Teacher in a Meaningful Context. Education and Global Society Challenges (143-149). Nowy Sącz: Państwowa Wyższa Szkoła Zawodowa, Poland.

- Janković, N. \& Ristić, M. (2018). Hand in hand - developing university teachers' and pre-service teachers' crosscurricular competences. In: Zacłona, Z. \& Radovanović, I. (Eds.). Chosen issues of education in the modern era (38-50). Nowy Sacz: State University of Applied Sciences and Belgrade: Teacher Education Faculty.

- Janković, N., Večanski, V. (2020). Educating pre-service teachers for integrated English language and Art activities with young learners. The teaching and learning process organization (170-190). Belgrade: Teacher Education Faculty and Nowy Sacz: State University of Applied Sciences.

- Kidd, W. \& Murray, J. (2020). The Covid-19 pandemic and its effects on teacher education in England: How teacher educators moved practicum learning online. European Journal of Teacher Education, 43 (4), 542-558, DOI: 10.1080/02619768.2020.1820480

- Kolb, D. A. (1984). Experiential learning: experience as the source of learning and development. Englewood Cliffs, NJ: Prentice Hall.

- Macaro, E. (1997). Target language, collaborative learning and autonomy. Clevedon, Avon: Multilingual Matters.

- Maile Cutri, R., Mena, J. \& Feinauer Whiting, E. (2020). Faculty readiness for online crisis teaching: transitioning to online teaching during the COVID-19 pandemic. European Journal of Teacher Education, 43 (4), 523-541.

- McIntyre, E., Kyle, D. W. \& Moore, G. H. (2006). A Primary-Grade Teacher's Guidance Toward Small-Group Dialogue. Reading Research Quarterly, 41 (1), 36-66.

- McLeod, S. (2014). The Interview Research Method. Simply Psychology. Retrieved November 5, 2021 from www: https://www.simplypsychology.org/interviews.html 
- Murdoch, K. \& Wilson, J. (2008). Creating A Learner-centred Primary Classroom: Learner-centred Strategic Teaching (A David Fulton Book). Routledge: Taylor and Francis Group.

- Nikolić, I. (2018). Opinion of teacher education faculties students about the concept of a quality school. In: Zacłona, Z. \& Radovanović, I. (Eds.). Chosen issues of education in the modern era (66-78). Nowy Sacz: State University of Applied Sciences and Belgrade: Teacher Education Faculty.

- Patton, M. Q. (2002). Qualitative research and evaluation methods (3rd ed.). Thousand Oaks, CA: Sage Publications.

- Rakich, S. S., Rodriguez, S. \& Morgan, R. (2020). The Transition of a School Counseling Program: The Shift From Traditional to Synchronous to Asynchronous Learning. In: Sistek-Chandler, C. M. (Ed.). Exploring Online Learning Through Synchronous and Asynchronous Instructional Methods (225-246). Hershey, PA, USA: IGI Global.

- Ristić, M., Vujović, A. (2020): Foreign language for specific purposes, digital framework and alternatives. The teaching and learning process organization (155-169). Belgrade: Teacher Education Faculty and Nowy Sacz: State University of Applied Sciences.

- Rowan, L. \& Bigum, C. (Eds.) (2012). Transformative Approaches to New Technologies and Student Diversity in Futures Oriented Classrooms: Future Proofing Education. Dordrecht: Springer Netherlands.

- Sepulveda-Escobar, P. \& Morrison, A. (2020). Online teaching placement during the COVID-19 pandemic in Chile: challenges and opportunities. European Journal of Teacher Education, 43 (4), 587-607.

- Sotillo, S. M. (2000). Discourse functions and syntactic complexity in synchronous and asynchronous communication. Language Learning \& Technology, 4 (1), 82-119. Retrieved September 3, 2021 from [http://lt.msu.edu/ vol4num $1 /$ sotillo/]

- Spratt, M. \& Leug, B. (2000). Peer teaching and peer learning revisited. ELT Journal, 54 (3), 218-226. July 2000, Retrieved July 2, 2021 from https://doi-org.eres.qnl.qa/10.1093/elt/54.3.218

- Tanasijević, M., Vukotić, A. (2014). The challenges of teaching ESP in traditional and virtual classrooms in Serbia at the academic level. In: Paunović, Z. (Ed.). English Language and Literature Studies: Embracing Edges (299-308). Beograd: Filološki fakultet.

- Tomović, N., Aleksić, M. (2020). Online nastava engleskog jezika u Srbiji tokom epidemije virusa COVID - 19. Komunikacija i kultura online, XI, 11. Retrieved August 11, 2021 from www: https://www.researchgate.net/publication/347881995_Online_nastava_engleskog_jezika_u_Srbiji_tokom_epidemije_virusa_COVID-19

- Trajanović, M., Domazet, D. i Mišić-Ilić, B. (2007). Distance Learning and Foreign Language Teaching. Research in Informatics and Information Society Technologies, 1, 441-452.

- Trajanović, M., Mišić Ilić, B. (2010). Iskustva u primeni sistema nastave na daljinu u nastavi engleskog jezika na Univerzitetu Metropolitan. U: Trajanović, M. (ur.) Zbornik radova sa nacionalne konferencije Elektronsko učenje na putu ka društvu znanja (61-67). Beograd: Univerzitet Metropolitan.

- Vilotijević, M., Mandić, D. (2015). Managing developmental changes in educational institutions. Beograd: Učiteljski fakultet.

- Vukotić, A., Tanasijević, M. (2012). Forms of communication in online English courses: making the most of new technologies in higher education. Primenjena lingvistika, 13, 7-16.

- Yang, A., Chan, A., Ho, L. K. \& Tam, B. (2005). Does an open forum promote learning among students? A collaborative-learning approach. Asian EFL Journal, 7 (3), 88-97. Retrieved February 12, 2006 from: http://www. asian-efl-journal.com/September_05_ay.php 


\section{APPENDIX 1 \\ FOCUS GROUP INTERVIEW - QUESTIONS FOR DISCUSSION}

1. Perceptions and experience of language learning online - what differences are there between language learning online and traditionally, in the classroom?

2. Perceptions and experience in language learning online - if it was easier or more difficult than learning in the traditional classroom context

2.1 Is it easier or more difficult to follow lectures online?

2.2 Language Skills

2.2.1 Is it easier or more difficult to do reading comprehension exercises online?

2.2.2 Is it easier or more difficult to do listening comprehension exercises online?

2.2.3 Is it easier or more difficult to follow instructions about writing essays and shorter written forms online?

2.2.4 Is it easier or more difficult to practice the skill of speaking online than in the classroom?

2.2.5.1 Is it easier or more difficult to prepare an oral presentation online?

2.2.5.2 Is it easier or more difficult to deliver an online presentation online?

2.2.6 Is it easier or more difficult to do grammar exercises online?

2.2.7. Is it easier or more difficult to do vocabulary exercises online?

3. Level of motivation for language learning online

4. Evaluate the course and the course delivery online

5. What are the challenges of learning English online, according to you?

6. What is the perspective of learning English online, according to you?

7. Do you have any other comment? Is there anything you would like to add? 


\section{Милена Ј. Танасијевић}

Универзитет Метрополитан, Београд, Србија

\section{Наташа 3. Јанковић}

Универзитет у Београду, Учитељски факултет, Београд, Србија

\section{НОВА ВИРТУЕЛНА СТВАРНОСТ - ПЕРЦЕПЦИЈЕ И ИСКУСТВО НАСТАВНИКА И СТУДЕНАТА У ВЕЗИ СА ОНЛАЈН-НАСТАВОМ И УЧЕЊЕМ ЕНГЛЕСКОГ ЈЕЗИКА}

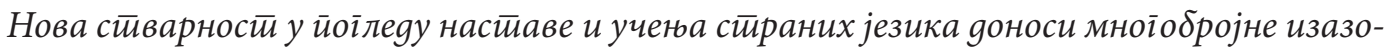
ве свима који учесиивују у образовном ироцесу - уиравама образовних инстииичиија, настиа-

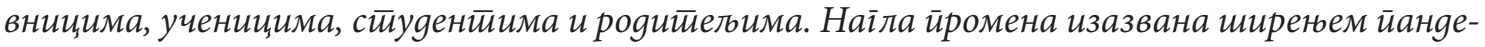
мије вируса корона gовела је мної у сииане стиреса и узнемиреносий. У раgу ойисујемо йроиес йреласка настиаве енїлескої језика са реgовних часова уживо на насииаву на gальну у ванреgним околносиима у gве високочколске устианове у Србији - Учииельском факулиеетиу Уни-

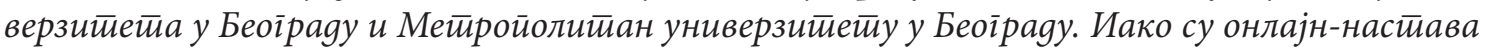
и учене стираних језика иррисуйни већ деценијама у високом образовань, хийности ирреласка

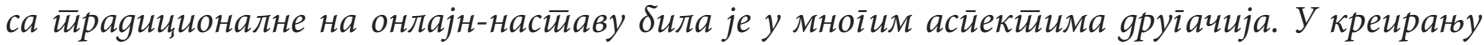
усиеешних онлајн-курсева сиираних језика кльчну улоіу има йрийремна фаза. У околносиичма

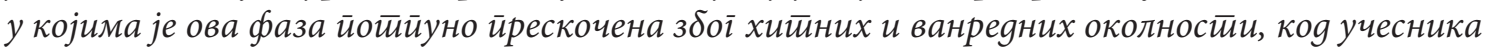
у настивном ирроцесу јавила су се већ йоменуйа осећаюа узнемиреносиии и сирреса.

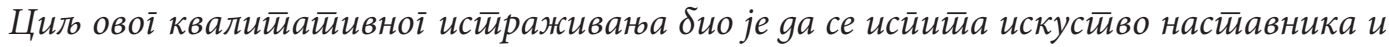

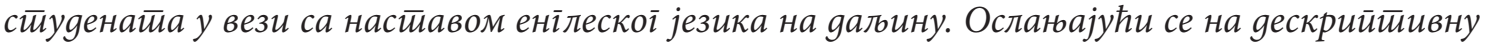
и рефлексивну мейоgу, као и на иниеервјуе са фокус іррииама, у раgу иррессииављамо искусивво

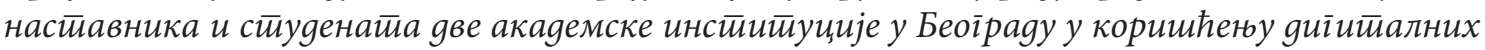
алайа и йлайборми за колабораииивно учене и йоуучаване на дальину, као шиио су зум (ені.

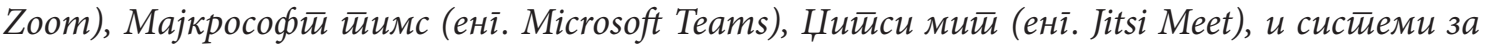
уиравльане онлајн-учетьем.

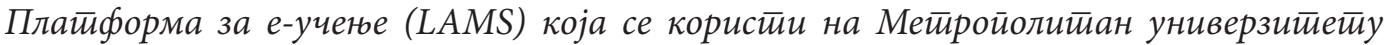

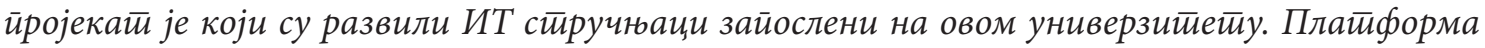
омоіућава йостивљьюе саяржаја и сиирукииуриране часова на начин на који би се одржали у иираяищионалној учионищи. Софбиввер за ириирему часова расйолаже gоgайним алаиимма

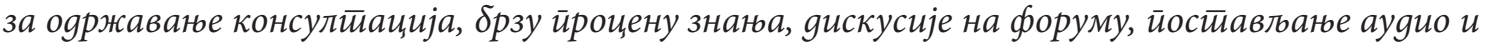
вияео саяржаја, као и слика, іррафикона и йадела. Плайформа задовољава мноіе иееgаїоике

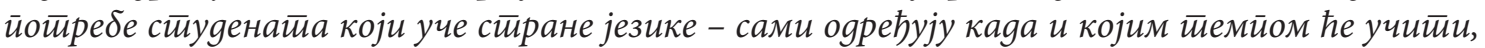

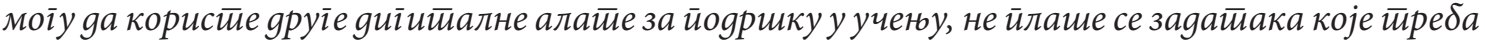
gа ураяе и моїу gа метьју и йрилаїођавају своје оgїоворе. С gруї с сиране, овај софйвер нема

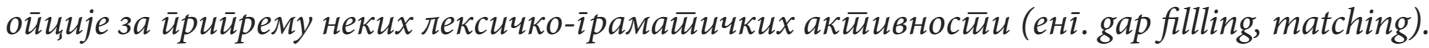

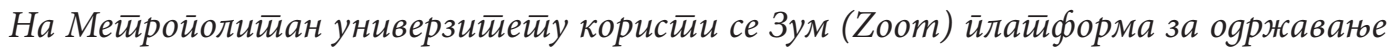
насииаве у реалном времену. $3 \delta о \overline{~ н е g о с т и а и к а ~ в р е м е н а ~ з а ~ и р р о и ̆ и с н о ~ и с и р а ж и в а ю е ~ и ~ и р р а к-~}$

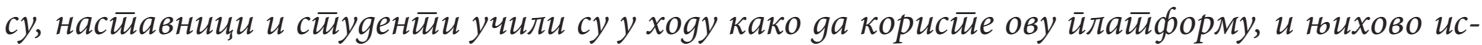

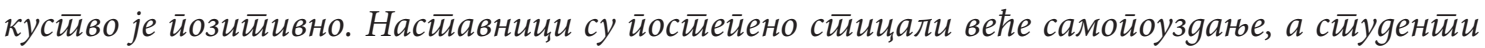


су учестивовали на часу ӣуйем ойије чети (ені. chat) или су усмено излаїали. Повремено су

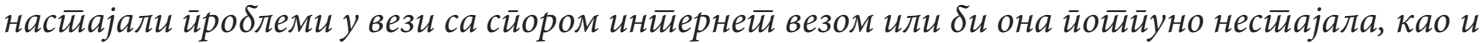
са йойребом за ређим коришћенем камере. Па ийак, временом је йримећено gа ойаgају енйузијазам и мотиивација међу стиуденииима.

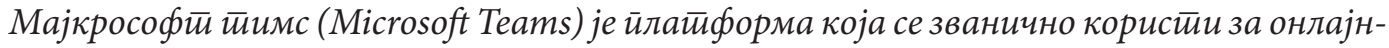

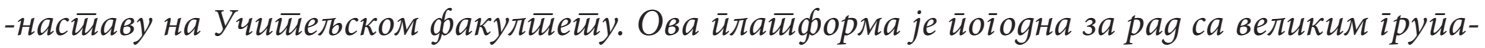

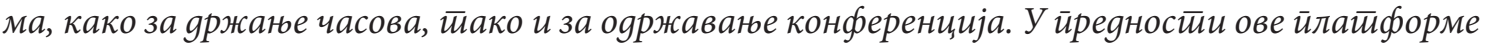

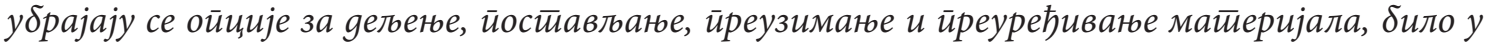

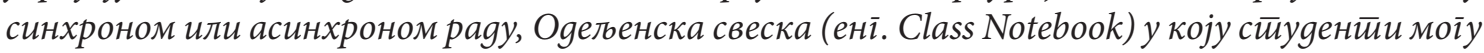
gа уносе белешке и йано за зајеgнички раg, као и йростиор йосебно наменен за йостиавтьане заgатиака, оцена и коменйара. Часови моїу gа се снимају и сачувају у заједничким фасииклама (ені. Team folders) pagи накнаgноі йреїлеgа. Оно шйо ову йлайборму чини сложеном за

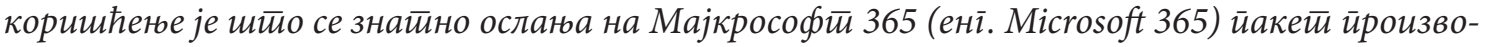

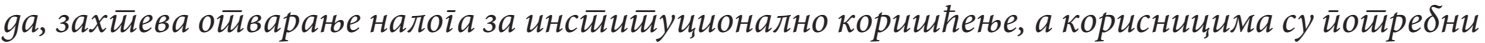
gоgайно време и обука gа науче gа уйойребљавају све моїућосиии које им ова йлайборма иружа.

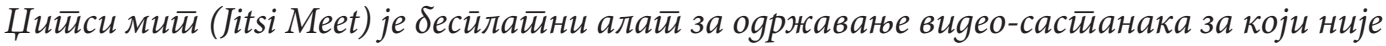
йотрребно gа се ойвара налої. Буяући gа омоїћава лако заказиване часова, gа има јеgнос-

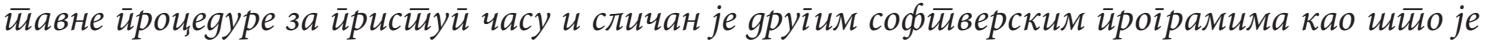
Скајй (ені. Skуре), овај алай је йослужио као иривремено решене за ояржаване насииаве из

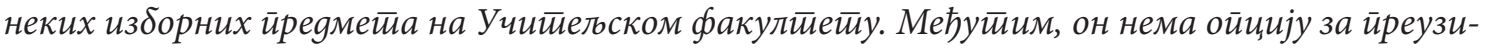

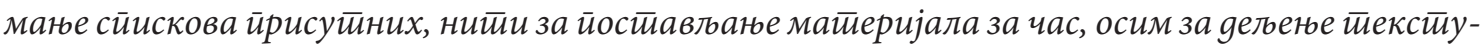
алних, ауgио и вияео саяржаја у тиоку часа.

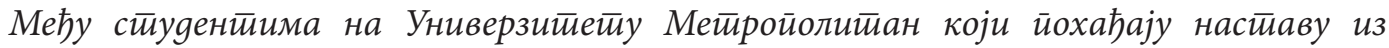

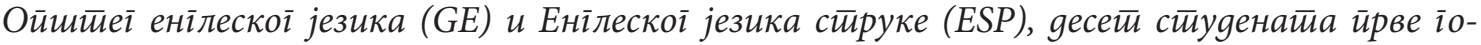

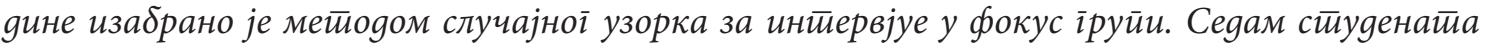

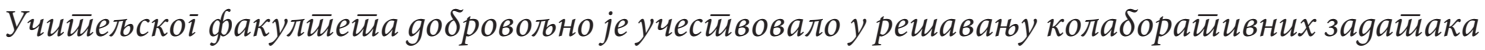

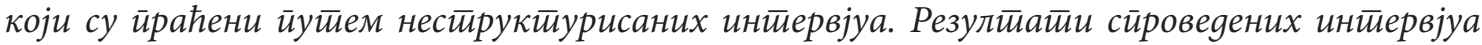

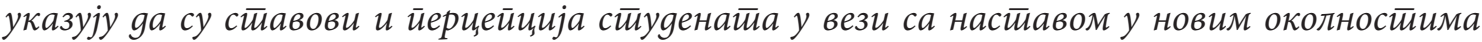

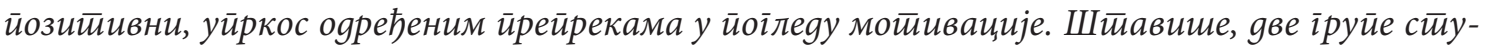
gенайа су колаборайивним раяом ӣрииремиле иррезенйаиију и раяионииу, које су йойом ирреgстиавиле на међунарояној конференцији о сиираном језику сиируке.

Овакви налази истираживаға моіу битии иоостиицај онима који су мағе мотиивисани

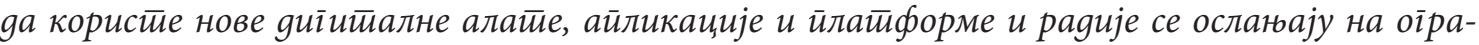
ничен избор синхроних и асинхроних облика онлајн-настиаве. Било би йакође корисно gа се

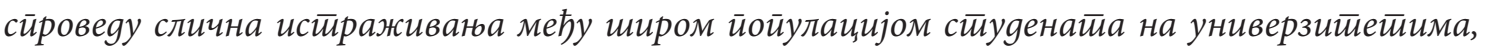
као и међу ученицима среgних школа и ниховим наситавницима како би се уйоредили нихо-

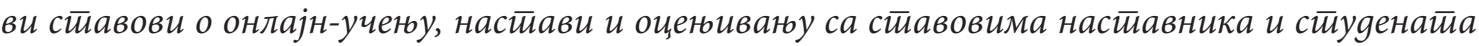
на универзитиетиу.

Учионииа нам свима неgосииаје. Али ово је време ӣромена. Колико іол незахвална била

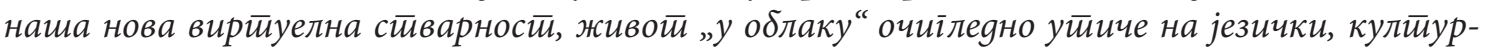




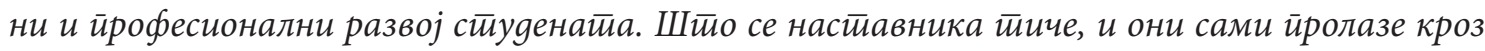
својеврсну яиіитиалну акулитурацију.

Клучне речи: насииава енїлескої језика, колаборайивно учење, онлајн-учене и йодучаване, енілески као језик настиаве (ЕМI), образовне йехнолоїије. 